\title{
KEBIJAKAN PERIZINAN, SENGKETA LINGKUNGAN HIDUP DAN KEPENTINGAN INVESTASI
}

\author{
Absori dan Nunik Nurhayati \\ Universitas Muhammadiyah Surakarta \\ abs154@ums.ac.id
}

\begin{abstract}
Abstrak
$\mathrm{K}$ ebijakan perizinana lingkungan dan kepentingan investasi disorot oleh banyak pihak, dianggap mempunyai andil besar yang menyebabkan krisis lingkungan di negeri ini. Perusakan dan pencemaran bidang lingkungan yang dilakukan pelaku usaha/industri dapat ditelusuri dari berbagai kebijakan pemberian perizinan lingkungan, seperti pendirian pabrik semen, penebangan HPH, reklamasi pantai, tambang batubara, emas dan lain lain. Perizinan lingkungan yang menimbulkan sengketa lingkungan apabila tidak bisa diselesaikan melalui hukum administrasi semata tetapi dapat juga dilakukan melalui hukum perdata bahkan pidana. Pembuktian hukum perdata biasa memerlukan pembuktian mengenai unsur hubungan sebab akibat, yang didasarkan pada dalil liabality base on fault dinilai akan memberatkan pihak yang melakukan gugatan. Karena itu dengan berkembangnya industrialisasi yang menghasilkan resiko yang bertambah besar serta makin rumitnya hubungan sebab-akibat, maka teori hukum telah meninggalkan konsep "kesalahan" dan berpaling ke konsep "resiko" yang menekankan pada tangung jawab mutlak dengan didasarkan pada asas liability base on risk. Model ke depan dalam penyelesaiaan sengketa perizinan lingkungan yang melibatkan masyarakat, pemerintah atau dunia usaha akan lebih baik apabila dilakukan melalui lembaga alternatif, dirancang melalui lembaga mediasi berdasarkan win win solution. Model penyelesaiaan ini merupakan model penyelesaiaan yang efisien, murah, cepat dan mampu menghasilkan keputusan yang lebih baik.
\end{abstract}

Kata Kunci: Perizinan lingkungan, Gugatan masyarakat dan Penyelesaian sengketa.

\section{Pendahuluan}

\section{Latar Belakang}

Manusia modern yang kapitalistik dan eksploitatif mempunyai andil besar mendorong manusia serakah terhadap lingkungan hidup. Manusia modern telah terjangkit penyakit yang tidak pernah puas dengan kebutuhan materi. Mereka memahami bahwa sumber daya alam adalah materi yang harus dieksploitasi untuk kepentingan pemenuhan kebutuhan materinya yang konsumtif. Peradaban modern yang dicapai melalui pembangunan industri telah mampu mengantarkan kehidupan manusia pada tingkat kesejahteraan yang luar biasa. Manusia modern telah menjadikan segala persoalan pemecahannya menjadi mudah. Di balik kesuksesan yang dicapai, manusia telah mengabaikan lingkungan, sehingga terjadi degradasi lingkungan yang amat mengkhawatirkan kehidupan manusia sendiri. ${ }^{1}$ Berbagai bencana Lingkungan hidup silih berganti, mulai kerusakan, pencemaran, bencana alam terjadi dimana-mana, dari tahun ke tahun akumulasi selalu bertambah, kerusakan terumbu karang, hutan, pencemaran air (sungai), darat dan udara sudah mencapai pada taraf yang amat mengkhawatirkan. Semuanya itu berkaitan dengan perilaku manusia yang menempatkan alam sebagai komoditas yang dieksploitasi tanpa menghiraukan daya dukung lingkungan yang bisa mengalami degradasi. ${ }^{2}$

\footnotetext{
1 Absori, Hukum Peenyelesaian engketa Lingkungan Hidup, Studi Pilihan Penyelesaian Sengketa lingkungan Hidup dengan Pendekatan Partisipatif, Muhammadiyah University Press, Surakarta, 2014, hal 1.

2 Lihat Absori, Khudzaifah Dimyati dan Ridwan “ Makna dan Pengeolaan Lingkungan, Perspektif Etik Propetik, Jurnal At-Tahrir STAIN Ponorogo, Vol 17 No 2, 2017, hal 2.
} 
Salah satu problem modernitas adalah masalah lingkungan (ekologis), beberapa dekade terakhir ini alam telah menjadi ancaman nyata bagi kelangsungan kehidupan umat manusia, ${ }^{3}$ walau sesungguhnya manusialah yang menjadi ancaman paling serius terhadap lingkungan, ketimbang organisme atau makhluk hidup lainnya. ${ }^{4}$ Solusi yang ditawarkan adalah kebijakan pembangunan yang memperhatikan adanya keberlanjuta yang dikenal dengan "pembangunan berkelanjutan". Pembangunan berkelanjutan pada satu sisi harus diletakan sebagai kebutuhan dan aspirasi manusia kini dan masa depan. Karena itu hak-hak asasi manusia seperti hak-hak ekonomi, sosial, budaya, dan hak atas pembangunan dapat membantu memperjelas arah dan orientasi perumusan konsep pembangunan yang berkelanjutan. Hak atas pembangunan tidak lepas dari ketentuan bahwa proses pembangunan haruslah memajukan martabat manusia, dan tujuan pembangunan adalah demi kemajuan yang terus menerus secara berkelanjutan untuk kesejahteraan manusia secara adil merata. Masyarakat internasional telah mensepakati pembangunan berkelanjutan sebagi model pembangunan masa depan. Demikian juga Indonesia telah mesepakati adanya action plan berupa kebijakan pembangunan berkelanjutan yang tidak semata berorientasi kepentingan ekonomi semata tetapi juga masa depan lingkungan. ${ }^{5}$

Menurut Emil Salim untuk melaksanakan pembangunan berkelanjutan dibutuhkan pendekatan ekosistem dengan melihat interdepedensi dari setiap komponen ekosistem. Agar keberlanjutan tetap terjaga harus ada komitmen setiap komponen penyangga kehidupan dan campur tangan pemerintah dengan melibatkan lembaga swadaya masyarakat. Dunia usaha yang selama ini dituduh sebagai pelaku yang menimbulkan kerusakan dan pencemaran harus dipahamkan akan tangung jawabnya terhadap lingkungan yang dapat diwujudkan dalam bentuk membayar kompensasi jasa lingkungan yang nantinya dapat digunakan untuk membiayai pemulihan lingkungan yang rusak atau tercemar. Disamping itu ntuk menuju hubungan lembaga Negara yang seimbang dibutuhkan chekcs and balances agar kepentingan antar lembaga Negara dapat dipelihara dengan baik. ${ }^{6}$

Di negara-negara maju biaya kebijakan lingkungan jauh-jauh hari sudah dipikirkan dampaknya dan dianggarkan dalam rencara pembiayaan dan pengeluaran oleh pemerintah penentu kebijakan ataupun perusahaan yang telah diberi izin untuk melakukan kegiatan usaha, baik dalam bidang usaha i ndustri atau pertambangan yang melakukan kegiatan eksplorasi maupun ekspoitasi yang berkaitan lingkungan. Dibalik kerusakan lingkungan adalah disebabkan oleh kegiaatan industri. ${ }^{7}$ Jika terdapat permasalahan yang berkaitan perizinan yang diberikan perusahaan bersedia menangung kompensasi dan jauh jauh hari perusahaan juga mengeluarkan secara rutin untuk pembiayaan lingkungan.

\section{Rumusan Masalah}

Tulisan ini akan membahas permasalahan (1) Bagaimana kebijakan yang berkaitan dengan perizinan lingkungan dan kepentingan investasi ? (2) Bagaimana gugatan perizinan lingkungan yang menimbulkan senekata lingkungan hidup ? dan (3) Bagaimana model penyelesiaan yang berkaiatan dengan perizinan lingkungan yang menimbulkan segketa lingkungan?

3 Corinne Le Quéré, "The implications of COP21 for our future climate," Public Health Reviews; Rennes: 37:29.(2016), hal 1.

4 Michael S. Hogue, "Global Warming And Religious Stick Fighting," Cross Currents; New York, (Spring 2007): 1.; lihat juga uraian Stephen PA. Brown, "Global Warming Policy: Some Economic Implications Economic Review - Federal Reserve Bank of Dallas; Dallas (Fourth Quarter 1998), 1.

5 Absori, Hukum Ekonomi Indonesia, Beberapa Aspek Pengembangan pada Era Liberalisasi Perdagangan, Muhammadiyah University Press Hukum, Surakarta, 2010, hal 7.

6 Emil Salim dalam Absori, Hukum Hukum Penyelesaian Sengketa Lingkungan, Muhammadiyah University Press, Surakarta, 2014, hal 167.

7 Rosa Chun, "Ethical Values and Environmentalism in China: Comparing Employees from State-Owned and Private Firms, ” Journal of Business Ethics, suppl. Supplement: JBE; Dordrecht_84. (Feb 2009): 341-348. 


\section{Metode Penulisan}

Metode penulisan yang digunakan adalah dengan pendekatan yuridis normatif yang dilakukan dengan mengumpulkan data yang berasal dari dokumen, referensi dan tulisan dari berbagai jurnal kemudian dianalisis dengan pendekatan deskriptif kualitatif.

\section{Pembahasan}

\section{Kebijakan Perizinan Lingkungan Dan Kepentingan Investasi}

Kebijakan perizinan lingkungan berkaitan dengan kebijakan peraturan/hukum (legal policy) diartikan bagaimana peraturan seharusnya dibuat dan dilaksanakan, dengan disertai pembinaan aparat pelaksana. Menurut paham neoliberal investor dianggap raja, diyakini dapat mengatasi problem pengangguran, membawa kemajuan, dan kesejahteraan. Apapun kemaunnya berusaha dipenuhi dari peroalan regulasi, perizinan, insentif dan kemudahan lain. Hukum sering dianggap sebagai faktor ekternal yang perlu disiasati. Dalam rangka pengembangan ekonomi yang berkelanjutan dibutuhkan peran hukum atau kebijakan. Karena itu harus ditegaskan pijakan prinsip prinsip pembaangunan secara konferenhensif mengingat sampai sekaarang belum terdapat kajian pengembangan hukum atau kebijakan dan ekonomi secara utuh. ${ }^{8}$

Kebijakan perizinana lingkungan yang berkaitan dengan kepentingan investasi disorot oleh banyak pihak, dianggap mempunyai andil besar yang menyebabkan krisis lingkungan di negeri ini . Perusakan dan pencemaran bidang lingkungan yang dilakukan pelaku usaha/industri dapat ditelusuri dari berbagai kebijakan pemberian perizinan lingkungan, seperti pendirian pabrik semen, pembukaaan perkebunana kelapa sawit, tambang batubara, emas dan lain lain.

Penelitian Disertasi Edy Lisdiyono (2008) menunjukan bahwa kebijakan hukum tata ruang, berupa Perda tentang Rencana Tata Ruang dalam tataran normatif dibuat untuk meligitimasi kebijakan pemerintah yang berpihak pada kepentingan pasar/ekonomi. Hal ini terlihat adanya Perda yang melegalkan kawasan konservasi (perbukitan, kawasan resapan air dan kawasan pesisir pantai) yang dilegalkan untuk kepentingan investasi. Dampaknya menimbulkan kerusakan lingkungan yakni tanah longsor, banjir dan banjir air pasang (rob). Lebih dari itu menimbulkan Konflik antara masyarakat dengan perusahaan dan pemerintah terutama dalam pembasan lahan dan terjadinya kerusakan/pencemaran lingkungan. ${ }^{9}$

Perizinan lingkungan juga berpotensi menimulkan korupsi, seperti yang dilakukan Wali Kota Cilegon, Tubagus Iman Ariyad yang ditangkap KPK karena diduga terlibat suap rekomendasi AMDAL perizinan pembangunan pusat perbelanjaan Transmart (Kompas, 24/9/2017). Kasus yang hampir sama diduga banyak dilakukan dalam pemberian perizinan dan penyusunan dokumen AMDAL. Persetujuan masyarakat sering dimanipulasi guna untuk memenuhi ketentuan administrasi perizinan lingkungan.

Menurut Sjachran Basah $^{10}$, perizinan berfungsi (1) Direktif, yaitu sebagai pengarah dalam pembangunan; (2) Integratif, yaitu sebagai pembina kesatuan komunitas, masyarakat, bangsa dan negara; (3) Stabilitas, yaitu sebagai pemelihara, termasuk memelihara hasilhasil pembangunan,(4) Perspektif, yaitu penyempurna langkah ke depan, berupa tindakan administrasi negara atau tindak warga masyarakat; (5) Korektif, yaitu memperbaiki thd tindakan administrasi negara dan warga masyarakat. Perizinan lingkungan sering dikenal dengan izin HO. ${ }^{11}$ Macam perizinan yang berkaiatan dengan lingkungan : (1) izin gangguan dilakukan dengan menggunakan Hinder Ordonantie (HO). (2) perizinan suatu proyek yang berdampak besar dan penting terhadap lingkungan diperlukan adanya analisis mengenai dampak lingkungan (Amdal), (3) perizinan untuk melakukan pembuangan limbah ke media lingkungan.

8 Absori, Deklarasi Pembangunan Berkelanjutan dan Implikasinya di Indonesia, Jurnal Ilmu Hukum, Fakultas Hukum Universitas Muhammadiyah Surakarta, Vol 9 No. 1, Maret 2006, hal 1.

9 Edy Lisdiyono, Desertasi Program Doktor Ilmu Hukum Universitas Diponegoro, Semarang, 2008, hal 1.

10 Lihat Absori, Hukum Penyelesaian Sengketa Lingkungan,, Studi Manifestasi Kekuatan Otonomi Masyarakat dalam Melakukan Penyelesaian Sengketa Lingkungan, Muhammadiyah University Press, Surakrata, 2014, hal 76.

11 Lihat Absori, Penegakan Hukum Lingkungan dan Antisipasi dalam Era Perdagangan Bebas, Muhammadiyah University Press, Surakarta, 2006, hal 37. 
Menurut Pasal 1 angka 35 UU No. 32 tahun 2009 tentang Perlindungan dan Pengelolaan Lingkungan Hidup Izin lingkungan adalah izin yang diberikan kepada setiap orang yang melakukan usaha dan/atau kegiatan yang wajib amdal atau UKL-UP dalam rangka perlindungan dan pengelolaan lingkungan hidup sebagai prasyarat untuk memperoleh izin usaha dan/atau kegiatan. Pasal 36 UU No. 32 Tahun 2009 yakni : (1). Setiap usaha dan/atau kegiatan yang wajib memiliki amdal atau UKL-UPL wajib memiliki izin lingkungan. (2) Izin lingkungan diterbitkan berdasarkan keputusan kelayakan lingkungan hidup atau rekomendasi UKL-UPL. (3) Izin lingkungan wajib mencantumkan persyaratan yang dimuat dalam keputusan kelayakan lingkungan hidup atau rekomendasi UKL-UPL. (4) Izin lingkungan diterbitkan oleh Menteri, gubernur, atau bupati/walikota sesuai dengan kewenangannya.

Amdal adalah kajian mengenai dampak penting suatu usaha dan/ata kegiatan yang direncanakan pada lingkungan hidup yang diperlukan bagi proses pengambilan keputusan tentang penyelenggaraan usaha dan/atau kegiatan. Sementara UKL-UPL adalah upaya pengelolaan lingkungan hidup dan upaya pemantauan lingkungan hidup terhadap usaha dan/ atau kegiatan yang tidak berdampak penting terhadap lingkungan hidup yang diperlukan bagi proses pengambilan keputusan tentang penyelenggaraan usaha dan/atau.

Pasal 37 ayat (1) UU No. 32 Tahun 2009 Menteri, gubernur, atau bupati/walikota sesuai dengan kewenangannya wajib menolak permohonan izin lingkungan apabila permohonan izin tidak dilengkapi dengan analisis dampak lingkungan (amdal ) atau Unit Kelola LingkunganUnit Pemantauan Lingkungan (UKL-UPL. Ayat (2) Izin lingkungan dapat dibatalkan apabila: a). persyaratan yang diajukan dalam permohonan izin mengan-dung cacat hukum, kekeliruan, penyalahgunaan, serta ketidakbenaran dan/atau pemalsuan data, dokumen, dan/atau informasi; b). penerbitannya tanpa memenuhi syarat sebagaimana tercantum dalam keputusan komisi tentang kelayakan lingkungan hidup atau rekomendasi UKL-UPL; atau c). kewajiban yang ditetapkan dalam dokumen amdal atau UKL-UPL tidak dilaksanakan oleh penanggung jawab usaha dan/atau kegiatan.

\section{Gugatan Sengketa Perizinan Lingkungan}

Pada era desentralisasi di Indonesia menjadikan peran stakeholders sangat menentukan terutama sebagai penyeimbang dan kontrol kebijakan. ${ }^{12}$ Peran pemerintah pusat dan daerah, kordinasi antar lembaga secara terpadu menjadi teramat penting. Lembaga perizinan lingkungan yang semula berada di Menteri Lingkungan Hidup pada saat sekarang melalui Peraturan Menteri dan Lingkungan No. 07 tahun 2014 telah dilimpahkan ke Badan Kordinasi Penanaman Modal (BKPM). Pelimpahan kewenangan izin lingkungan ke BKPM dimaksudkan untuk mempermudah investasi di Indonesia melalui kebijakan pelayanan perizinan satu pintu. Pelimpahan izin lingkungan ke BKPM menui sejumlah kritik dengan alasan kalau perizinan lingkungan dilimpahkan ke BKPM dengan alasan kemudah investasi akan berpotensi mengabaikan pertimbangan lingkungan karena otoritas pemberian perizinan lingkungan berada di tangan BKPM, sementara Kementerian Lingkungan dan Kehutanan hanya menjadi bagian saja atau sub BKPM, sehingga yang bertindak untuk dan atas nama menteri adalah BKPM.

Dalam tataran implementasi akan menyulitkan dalam pengawan kegiatan usaha industri yang telah diizinkan. Hal ini berpotensi terjadi pelanggaran lingkungan yang sulit diawasi. Selama ini institusi pengawas dilakukan menteri yang ditugasi untuk mengelola lingkungan hidup, yakni Menteri Lingkungan Hidup untuk melakukan pengawasan terhadap penataan yang berkaitan dengan pengelolaan lingkungan hidup. Dalam perizinan pendirian usaha atau kegiatan usaha menteri juga berwenang melakukan pengawasan atas semua ketentuan yang berkaitan dengan izin yang diberikan. Menurut Sony Keraf (Kompas, 2016) izin lingkungan yang telah didelegasikan ke BKPM hanya bersifat prosedur formal. Padahal izin lingkungan

12 M Syblunnur, Absori dan Wujoso, Perlindungan Hukum Pelayanan Kesehatan Tingkat Pertama di Kabupaten Kota Waringin Timur, Tesis, Pascasarjana, Universitas Muhammadiyah Surakarta, 2017, hal 21. 
bersifat fundamental dan kunci utama untuk memastikan pembangunan di tingkat pelaksanaan aman dan dapat dikendalikan dampaknya terhadap lingkungan

Izin lingkungan bukanlah sekedar izin formal atau kelengkapan dokumen tetapi perlu pengecekan, pembuktian dan kajian ilmiah yang memastikan pembangunan yang akan dilakukan dapat dikendalikan dampaknya. Di sini terlihat bahwa satu sisi akan memudah investor tetapi pada sisi lain pembangunan berkelanjutan dilemahkan. Karena itu, kebijakan tersebut dianggap sebagai kemunduran besar dari semangat UU No. 32 tahun 2009 tentang Perlindungan dan Pengelolaan Lingkungan Hidup. Ketentuan sanksi administrasi dalam UU No. 32 Tahun 2009 diatur dalam Pasal 76 disebutkan Menteri, gubernur, atau bupati/walikota dapat menerapkan sanksi administratif kepada penanggung jawab usaha dan/atau kegiatan jika dalam pengawasan ditemukan pelanggaran terhadap izin lingkungan. Penyelesaian sengketa lingkungan dapat juga diajukan ke Pengadilan Tata Usaha Negara (PTUN). Dalam hal ini PTUN mempunyai kewenangan menjatuhkan sanksi administrasi melalui keputusan administrasi terhadap perizinan yang telah dikeluarkan pejabat yang berwenang.

Gugatan perizinana lingkungan dapat dikategorikan sebagai sengketa administrasi merupakan bentuk respon terhadap petaka lingkungan, dimana masyarakat yang menjadi korban dan peduli lingkungan berusaha untuk melakukan penuntutan dalam rangka untuk meindung lingkungan. ${ }^{13}$ Sebagai contoh yang dilakukan masyarakat Rembang yang menggugat pemberian perizinan pendirian pabrik PT Semen Indonesia di Watu Putih, Gunem, Rembang. Objek gugatan adalah Putusan Gubernur Jateng No. 660.1/17/2012 tanggal 7 tahun 2012 tentang Izin Lingkungan Kegiatan Penambangan Pabrik Semen PT Semen Indonesia. Gugatan perizinan memiliki tengang waktu 90 hari sejak izin pendirian pabrik semen diberikan, yakni Juni 2012 sedang masyarakat mengajukan gugatan 1 September 2014. Hakim berpendapat tidak perlu lagi mempertimbangkan materi pokok gugatan dan materi yang lain. Alasan lain masyarakat sebenarnya telah diberi sosialisasi sebelum perizinan diberikan, serta silaturakhmi ke warga masyarakat.

Majelis hakim PTUN Semarang, yang diketuai Susilowati Siahaan tidak bisa menerima gugatan dengan alasan gugatan diajukan telah kedaluwarsa Masyarakat kawan Kecamatan Gunem dan Bulu Rembang mengajukan banding ke PTTUN Surabaya tetapi putusanya gugatan ditolak. Masyarakat kemudian mengajukan kasasi ke MA, namun putusannya juga ditolak. Akhirnya masyarakat bersama penesehat hukumnya Joko Prianto mengajukan PK pada 4 Mei 2016 setelah menemukan bukti baru (novum) memenangkan gugatan warga Rembang atas pendirian PT Semen Indonesia dan Gubernur Jawa Tengah, Ganjar Pranowo diminta untuk mematuhi putusan MA.

Di Jakarta masyarakat (nelayan) yang tidak setuju proyek reklamasi pantai telah menggugat ke PTUN Jakarta dengan alasan merusak lingkungan dan melanggar UU No. 32 Tahun 2009. Gugatan masyarakat telah dikabulkan PTUN Jakarta dengan keputusan No. 193/G/LH/2015 berisi membatalkan Keputusan Gubernur DKI Jakarta No. 2238 Tahun 2014 tentang Pmeberian Izin Pelaksanaan Reklamasi Pulau G. Belakangan Menteri Koordinator Bidang Kemaritiman, Ruhut Binsar Panjaitan membolehkan PT Muara Wasesa melanjutkan reklamasi dengan alasan bahwa putusan PTUN masih belum tetap (in kracht) karena pemerintah telah mengajukan banding dan beranggapan masih mempunyai kewenangan untuk melanjutkan proyek relakmasi pulau G. Belakangan kebijakan reklamasi pantai sementara dihentikan sambil menunggu adanya kepastian yang didasarkan kesepakatan antara pemerintah pusat dan Gubernur terpilih.

Dalam hokum perdata penyelesaian sengketa lingkungan dapat dilakukan dengan instrumen hukum perdata biasa memerlukan pembuktian mengenai unsur hubungan sebab akibat, antara perbuatan dengan kerugian penderita yang dibebankan kepada penggugat sebagai korban. Dalil pembutian Pembuktian menurut Pasal 1865 KUHPerd. disebutkan

13 Absori, Penegakan Hukum Lingkungan Pada Era Reformasi, Jurnal Ilmu Hukum, Fakultas Hukum Universitas Muhammadiyah Surakarta, Vol 8 No. 2, September 2005, hal 222. 
bahwa "barang siapa mengajukan peristiwa atas nama ia mendasarkan sesuatu hak, diwajibkan membuktikan peristiwa-peristiwa itu, sebaliknya barang siapa mengajukan peristiwa-peristiwa guna membantah hak orang lain, diwajibkan untuk membuktikan peristiwa-peristiwa itu" Pembuktian perdata mendasarkan pada liabality base on fault. Dalil pembuktian tersebut dinilai akan memberatkan pihak yang melakukan gugatan, karena untuk melakukan tuntutan ganti rugi pihak penggugat harus bisa membuktian adanya unsur kesalahan pada pihak tergugat.

Dalam kasus sengketa sengketa di PN Palembang yang dipimpin Parlas Nababan pada tanggal 30 Desember 2015 telah menolak tuntutan ganti rugi Kementerian Lingkungan Hidup dan Kehutanan Rp. 7,9 Triliun kepada PT Bumi Mekar Hijau dengan tuduhan telah membakar hutan. Pertimbangan hakim bahwa pembakaran hutan yang dilakukan PT Bumi Mekar Hijau tidak merusak lahan karena masih bisa ditanami. Alasan tersebut dianggap tidak masuk akal karena hutan atau lahan yang terbakar akan russak tidak hanya fungsi produksi, tetapi juga konservasi dan lindung, juga kerusakan tanah dan mikroba. Dalam fakta dilapangan perusahaan tidak memiliki sarana dan prasarana pemadam kebakaran yang memadai.

Terhadap putusan PN Palembang, kemudian Kementerian LKHK melakukan banding ke PT Palembang, Sumatera Selatan. Memori banding berisi agar hakim yang akan mengadili menggunakan argumen hukum prinsip tanggung jwab mutlak (strict liability). Pembuktian dilakukan secara terbalik atau perusahaan harus bertangung jawab seacara hukum tanpa perlu dibuktiakan perbuatannya sengaja atau lalai. Pasal 88 UU No. 32 Tahun 2009 "Setiap orang yang tindakannya, usahanya, dan/atau kegiatannya menggunakan B3, menghasilkan dan/atau mengelola limbah B3, dan/atau yang menimbulkan ancaman serius terhadap lingkungan hidup bertanggung jawab mutlak atas kerugian yang terjadi tanpa perlu pembuktian unsur kesalahan". Menurut James E. Krier, azas tanggung jawab mutlak merupakan bantuan yang besar dalam peradilan mengenai kasus-kasus lingkungan. ${ }^{14}$ Karena banyak kegiatan yang menurut pengalaman menimbulkan kerugian terhadap lingkungan merupakan tindakan yang berbahaya, untuk itu dapat diberlakukan ketentuan tanggung jawab tanpa kesalahan.

Menurut Rudiger Lummert dengan berkembangnya industrialisasi yang menghasilkan resiko yang bertambah besar serta makin rumitnya hubungan sebab-akibat, maka teori hukum telah meninggalkan konsep "kesalahan" dan berpaling ke konsep "resiko". ${ }^{15}$ Pasal 87 ayat (1) UU No. 32 Tahun 2009 menyebutkan "Setiap penanggung jawab usaha dan/atau kegiatan yang melakukan perbuatan melanggar hukum berupa pencemaran dan/atau perusakan lingkungan hidup yang menimbulkan kerugian pada orang lain atau lingkungan hidup wajib membayar ganti rugi dan/atau melakukan tindakan tertentu".

\section{Model Penyelesiaan Sengketa Lingkungan dalam Perizinan Lingkungan $Y$}

Model ke depan dalam penyelesaiaan sengketa perizinan lingkungan yang melibatkan masyarakat dengan pemerintah atau dunia usaha akan lebih baik apabila dilakukan melalui lembaga alternatif, yakni dirancang melalui lembaga dengan mediasi. Di dalamnya terdapat proses sengketa bagaimana baiknya berdasarkan win win solution. Model penyelesaiaan ini merupakan model penyelesaiaan yang efisien, murah, cepat dan mampu menghasilkan keputusan yang lebih baik. ${ }^{16}$ Disamping itu, alasan lain penyelesaian sengketa lingkungan yang dilakukan melalui pengadilan keputusannya kurang mengasilkan keputusan yang memuaskan para pihak dan waktu yang dibutuhkan terlalu lama. Model penyelesaiaan sengketa alternative melalui media menurut C.W. Moore digambarkan sebagai intervensi terhadap suatu sengketa atau negosiasi oleh pihak ketiga yang dapat diterima, tidak berpihak dan netral, kesepakatan

14 James E. Krier dalam Absori, Op Cit, hal 118. Lebih lanjut lihat Koesnadi Hardjosoemntri, Hukum Tata Lingkungan, Gadjahmada University Press, Yogyakarta 2000, hal 336.

15 Rudiger Lummert dalam Absori, Op Cit, hal 117. Lebih lanjut lihat Koesnadi Hardjosoemntri, Hukum Tata Lingkungan, Gadjahmada University Press, Yogyakarta, 2000 hal 334.

16 Absori, Model Penyelesaian Sengketa Lingkungan Melalui Lembaga Alternatifi, Jurnal Mimbar Hukum, Fakultas Hukum Universitas Gadajmada, Yogyakarta, Vol 20 No. 2, Juni 2008, hal 368. 
yang dihasilkan suka rela akan dapat menyelesaiakan masalah yang disengketakan kedua belah pihak. ${ }^{17}$ Konsep penyelesaian sengketa, termasuk sengketa lingkungan kiranya perlu dipertimbangkan dengan mengembangkan model pendekatan humanisme transcendental, yang menekankan pendekatan pentingnya aspek manusia untuk berbuat baik (tamuru bil maruf) dan berusaha mencegah kemungkaran dengan semata menyerahkan putusannya pada ketentuan ilahiyah sebagai bentuk dan komitmen manusia yang beriman. ${ }^{18}$

\section{Penutup}

Kebijakan perizinan lingkungan berkaitan dengan kebiajakan peraturan/hukum (legal policy) diartikan bagaimana peraturan seharusnya dibuat dan dilaksanakan, dengan disertai pembinaan aparat pelaksana. Menurut paham neoliberal investor dianggap raja, diyakini dapat mengatasi problem pengangguran, membawa kemajuan, dan kesejahteraan. Apapun kemaunnya berusaha dipenuhi dari peroalan regulasi, perizinan, insentif dan kemudahan lain. Hukum sering dianggap sebagai faktor ekternal yang perlu disiasati. Kebijakan perizinana lingkungan yang berkaitan dengan kepentingan investasi disorot oleh banyak pihak, dianggap mempunyai andil besar yang menyebabkan krisis lingkungan di negeri ini . Perusakan dan pencemaran bidang lingkungan yang dilakukan pelaku usaha/industri dapat ditelusuri dari berbagai kebijakan pemberian perizinan lingkungan, seperti pendirian pabrik semen, pembukaaan perkebunana kelapa sawit, tambang batubara, emas dan lain lain.

Berkaitan dengan perizinan lingkungan yang menimbulkan sengketa lingkungan apabila tidak bias diselesaikan melalui hokum administrasi dapat juga dilakukan melalui hukum perdata bahkan pidana. Dalam hokum perdata penyelesaian sengketa lingkungan dapat dilakukan dengan instrumen hukum perdata biasa memerlukan pembuktian mengenai unsur hubungan sebab akibat, antara perbuatan dengan kerugian penderita yang dibebankan kepada penggugat sebagai korban. Dalil pembutian liabality base on fault dinilai akan memberatkan pihak yang melakukan gugatan, karena untuk melakukan tuntutan ganti rugi pihak penggugat harus bisa membuktian adanya unsur kesalahan pada pihak tergugat. Karena itu dengan berkembangnya industrialisasi yang menghasilkan resiko yang bertambah besar serta makin rumitnya hubungan sebab-akibat, maka teori hukum telah meninggalkan konsep "kesalahan" dan berpaling ke konsep "resiko" yang menekankan pada tangung jawab mutlak dengan didasarkan pada asas liability base on risk.

Model ke depan dalam penyelesaiaan sengketa perizinan lingkungan yang melibatkan masyarakat dengan pemerintah atau dunia usaha akan lebih baik apabila dilakukan melalui lembaga alternatif, yakni dirancang melalui lembaga dengan mediasi berdasarkan win win solution. Model penyelesaiaan ini merupakan model penyelesaiaan yang efisien, murah, cepat dan mampu menghasilkan keputusan yang lebih baik. Disamping itu, alasan lain penyelesaian sengketa lingkungan yang dilakukan melalui pengadilan keputusannya kurang mengasilkan keputusan yang memuaskan para pihak dan waktu yang dibutuhkan terlalu lama.

\section{Daftar Pustaka}

Absori, Hukum Penyelesaian engketa Lingkungan Hidup, Studi Pilihan Penyelesaian Sengketa lingkungan Hidup dengan Pendekatan Partisipatif, Muhammadiyah University Press, Surakarta, 2014.

Absori, Hukum Ekonomi Indonesia, Beberapa Aspek Pengembangan pada Era Liberalisasi Perdagangan, Muhammadiyah University Press Hukum, Surakarta, 2010

Absori, Deklarasi Pembangunan Berkelanjutan dan Implikasinya di Indonesia, Jurnal Ilmu Hukum, Fakultas Hukum Universitas Muhammadiyah Surakarta, Vol 9 No. 1, Maret

17 Absori, Op Cit, hal 373.

18 Absori, Kelik dan Saepul Rochman, Huku Profetik, Kritik terhadap Paradigma Hukum Non Sistemik, Genta Pulishing, Yogyakarta, 2015, hal 259. 
2006.

Absori, Penegakan Hukum Lingkungan dan Antisipasi dalam Era Perdagangan Bebas, Muhammadiyah University Press, Surakarta, 2006, hal 37.

Absori, Penegakan Hukum Lingkungan Pada Era Reformasi, Jurnal Ilmu Hukum, Fakultas Hukum Universitas Muhammadiyah Surakarta, Vol 8 No. 2, September 2005.

Absori, Model Penyelesaian Sengketa Lingkungan Melalui Lembaga Alternatifi, Jurnal Mimbar Hukum, Fakultas Hukum Universitas Gadajmada, Yogyakarta, Vol 20 No. 2, Juni 2008.

Corinne Le Quéré, “The implications of COP21 for our future climate, ” Public Health Reviews; Rennes: 37:29.(2016).

Edy Lisdiyono, Disertasi Progaram Doktor Ilmu Hukum Universitas Diponegoro, Semarang, 2008.

Hamzah, Penegakan Hukum Lingkungan, Arikha Media Cipta, Jakarta, 2005.

Koesnadi Hardjosoemantri, Hukum Tata Lingkungan, Gadjahmada University Press, Yogyakarta, 2000.

Lynn White dalam Salihuddin Djalal Tanjung, Industrialisasi dan Lingkungan Hidup dalam perspektif Ekologis, 1995.

M Syblunnur, Absori dan Wujoso, Perlindungan Hukum Pelayanan Kesehatan Tingkat Pertama di Kabupaten Kota Waringin Timur,, Tesis, Pascasarjana, Universitas Muhammadiyah Surakarta, 2017.

Mas Akhmad Santoso, Good Governance dan Hukum Lingkungan, ICEL, Jakarta, 2001.

Michael S. Hogue, “Global Warming And Religious Stick Fighting," Cross Currents; New York, (Spring 2007).

Rosa Chun, "Ethical Values and Environmentalism in China: Comparing Employees from State-Owned and Private Firms," Journal of Business Ethics, suppl. Supplement: JBE; Dordrecht.84. (Feb 2009).

Rachamadi Usman, Pembaharuan Hukum Lingkungan Nasional, Citra Aditya Bhakti, Bandung, 2003.

Sudharto P. Hadi, Resolusi Konflik Lingungan, Badan Penerrbit Universitas Diponegoro, Semarang, 2004. 